\title{
Auxin and Flower Development: A Blossoming Field
}

\author{
Mara Cucinotta, ${ }_{1}^{1}$ Alex Cavalleri, ${ }^{1}$ John William Chandler, ${ }^{2}$ and Lucia Colombo ${ }^{1}$ \\ ${ }^{1}$ Dipartimento di Bioscienze, Università degli Studi di Milano, 20133 Milan, Italy \\ ${ }^{2}$ Max Planck Institute for Plant Breeding Research, 50829 Cologne, Germany \\ Correspondence: lucia.colombo@unimi.it
}

The establishment of the species-specific floral organ body plan involves many coordinated spatiotemporal processes, which include the perception of positional information that specifies floral meristem and floral organ founder cells, coordinated organ outgrowth coupled with the generation and maintenance of inter-organ and inter-whorl boundaries, and the termination of meristem activity. Auxin is integrated within the gene regulatory networks that control these processes and plays instructive roles at the level of tissue-specific biosynthesis and polar transport to generate local maxima, perception, and signaling. Key features of auxin function in several floral contexts include cell nonautonomy, interaction with cytokinin gradients, and the central role of MONOPTEROS and ETTIN to regulate canonical and noncanonical auxin response pathways, respectively. Arabidopsis flowers are not representative of the enormous angiosperm floral diversity; therefore, comparative studies are required to understand how auxin underlies these developmental differences. It will be of great interest to compare the conservation of auxin pathways among flowering plants and to discuss the evolutionary role of auxin in floral development.

\begin{abstract}
A ngiosperm flowers display extraordinary diAversity in their body plan and every aspect of morphology, including organ number and positioning, size, symmetry, color, and organogenesis. The study of select angiosperm species has elaborated the genetic basis of floral identity according to the coordinated expression of transcription factors. However, advances in auxin biology have demonstrated that auxin is a central developmental regulator of floral morphogenesis (Irish 2010; Wellmer et al. 2014).

Auxin is essential for the initiation of floral meristems (FMs) and organs and for terminating meristem growth; however, its role in deter-
\end{abstract}

mining positional information for floral organ initiation remains less mechanistically well understood than its function in organ outgrowth and development (Chandler 2011). Auxin can also function as a morphogen by generating response gradients, particularly in combination with those of cytokinins, which are instrumental in several aspects of floral organogenesis (Su et al. 2011).

This review summarizes how auxin coordinates diverse and complex regulatory gene networks in FM and organ initiation and development and focuses on the Arabidopsis model for which most is known. It also highlights the cen-

Editors: Dolf Weijers, Karin Ljung, Mark Estelle, and Ottoline Leyser

Additional Perspectives on Auxin Signaling available at www.cshperspectives.org

Copyright (C) 2021 Cold Spring Harbor Laboratory Press; all rights reserved; doi: 10.1101/cshperspect.a039974

Cite this article as Cold Spring Harb Perspect Biol 2021;13:a039974 
M. Cucinotta et al.

tral role of canonical and noncanonical auxin response factors (ARFs) such as MONOPTEROS (MP) and ETTIN (ETT/ARF3), respectively.

\section{AUXIN IS ESSENTIAL FOR FLORAL MERISTEM INITIATION}

Floral organ primordia arise from FMs, which initiate as lateral organs at the inflorescence meristem (IM) periphery. The maintenance of the IM required a precise balance between the self-renewal of stem cells and cell differentiation. It has been proposed that the WUSCHEL (WUS) transcription factor achieves this balance by restricting auxin signaling in stem cells and simultaneously allowing low levels of auxin signaling output (Ma et al. 2019), although the precise mechanism of this rheostat function on select auxin signaling components remains to be elucidated.

Precise spatiotemporal local auxin biosynthesis within the IM and its polar transport and accumulation at specific sites from sources elsewhere in the plant are essential for FM initiation (Alvarez-Buylla et al. 2010; Yadav et al. 2019). This is evidenced by classical mutants, for example, in PIN-FORMED1 (PIN1), which encodes a polar auxin efflux carrier (Gälweiler et al. 1998). Occasional flowers on pin 1 inflorescences lack sepals and have a variable number of abnormally shaped petals (Okada et al. 1991) and exogenous auxin application to pin1-1 inflorescences restores flower formation at the point of application (Reinhardt et al. 2000). Mutation of the gene encoding the PINOID (PID) kinase that regulates PIN activity leads to flowers with supernumerary petals, few sepals and stamens, and mostly pin-like carpels (Bennett et al. 1995). Strong mutants of ARF5/MONOPTEROS (MP) produce naked inflorescences (Przemeck et al. 1996), although the hypomorphic mpS319 allele occasionally produces rudimentary flowers (Alonso et al. 2003; Cole et al. 2009). Lossof-function of MACCHI-BOU4 (MAB4)/ ENHANCER OF PINOID (ENP)/NAKED PINS IN YUC MUTANTS 1 (NPY), hereafter MAB4, which encode NONPHOTOTROPIC HYPOCOTYL 3-like proteins that regulate PIN endo- cytosis, also causes pin-like inflorescences (Furutani et al. 2014), due to the abolition of auxin flow from external FM layers inward to create an auxin sink necessary for FM development after initiation.

Auxin response maxima prepattern sites of FM initiation at the IM periphery (Reinhardt et al. 2000), and in addition to the importance of the spatial distribution of auxin within the SAM as an instructive signal, recent high-resolution imaging of auxin response has revealed the importance of a dynamic temporal component to these auxin fluxes (Galvan-Ampudia et al. 2020). In this scenario, high-precision dynamic spatiotemporal auxin gradients within the IM periphery are coordinated with growth, to ensure that cells are exposed to a high level of auxin over time to activate organogenesis. The temporal aspect concerning the timing and duration of exposure of cells to high auxin is relevant because, according to phytomer theory, FMs initiate as lateral organs in the axils of bracts. Arabidopsis bracts are cryptic but are histologically and morphologically visible during early floral transition preceding FM initiation (Kwiatkowska 2008). Transcriptional reprogramming associated with bract initiation has been accessed in the ap1 cal mutant background by sorting cells that express the bract foundercell marker DORNROESCHEN-LIKE (DRNL) (Frerichs et al. 2016). Minor transcriptional changes in genes in the auxin synthesis, transport, and response machinery suggest that its global activation might not be associated with bract initiation, but with FM initiation. This is consistent with spatially distinct domains of $D R N L$ and DR5 expression within the IM (Chandler et al. 2011) and that auxin response minima are required for the formation of axillary vegetative meristems in Arabidopsis and tomato (Wang et al. 2014a,b). Interacting concentration gradients of auxin and cytokinin establish the timing of FM outgrowth within the IM, which can be uncoupled from initiation (Besnard et al. 2014).

An early feature of FM initiation is inhibition of the pluripotency of stem cells that form FM primordia, by down-regulation of SHOOTMERISTEMLESS (STM). Transcripts of STM 
overaccumulate in the IM of $m p S 319$ and more so in an $m p$ arf3 arf4 triple mutant, resulting in complete loss of flower primordia. ETT directly binds to STM and silences its expression for FM fate acquisition. By contrast, MP does not bind $S T M$, but directly activates expression of the repressor FILAMENTOUS FLOWER (FIL), which further contributes to STM silencing. ETT and FIL also directly bind and repress expression of BREVIPEDICELLUS (BP), which maintains meristematic identity. Although MP, ETTIN, and ARF4 repress STM and BP expression in parallel pathways, FIL physically interacts with ETTIN and ARF4 to create a complex that recruits chromatin modifiers such as histone deacetylase HDA19, which leads to target-gene silencing (Table 1; Fig. 1; Chung et al. 2019).

\section{THE CENTRAL ROLE OF MP IN FM DEVELOPMENT}

MONOPTEROS is the central regulator of FM development and translates a local auxin concentration maximum into a floral primordium by directly transcriptionally activating several transcription factors. These include the master regulator $L E A F Y(L F Y)$, which, together with its target APETALA1, regulates the IM-to-FM identity transition (Weigel et al. 1992). LFY expression in incipient flower primordia is enhanced by high auxin levels, via the canonical MP/IAA12 (BODENLOS) module (Yamaguchi et al. 2013). LFY expression only partially rescues mp-S319 flower defects and MP also transcriptionally activates AINTEGUMENTA (ANT) and AINTEGUMENTA-LIKE6 (AIL6), which function in parallel and redundantly with LFY in FM initiation. Because the $l f y-6$ ant-4 ail6-2 triple mutant initiates some flowers, additional auxin-regulated factors probably contribute to FM production. ANT and AIL6 also function upstream of $L F Y$ and regulate its expression in response to auxin and in parallel to MP. Accordingly, they are expressed earlier than LFY (Yamaguchi et al. 2016) and delayed LFY expression in ant ail6 delays FM production. However, expression of ANT and AIL6 in $m p$ is reduced but not abolished (Yamaguchi et al. 2013), suggesting that they are also regulated independently from MP, potentially via other ARFs.

In summary, MP triggers FM initiation and development by transcriptionally up-regulating $L F Y, A N T$, and AIL6 via two separate pathways in which $L F Y$ both targets ANT/AIL6 and acts in parallel with them. In addition, LFY positively feedbacks into the auxin pathway, to ensure maintenance of the auxin response network and to lock the auxin response in an "on" state that ensures commitment to flowering (Table 1; Fig. 1). Expression of DR5er:GFP positively correlates with LFY activity, and feedback regulation on auxin signaling by LFY occurs partly by up-regulation of PID expression (Li et al. 2013; Yamaguchi et al. 2013).

The reprogramming of MP targets in meristematic cells that develop into floral primordia involves chromatin remodeling via the SWI/ SNF ATPases BRAMA (BRM) and SPLAYED $(S Y D)$, which increase chromatin accessibility in early floral primordia. Initiation of fewer flower primordia and pin-like inflorescences in mpS319 syd double mutants and mpS319 plants expressing an artificial microRNA responsible for BRAHMA down-regulation demonstrate the functional relevance of $B R M$ and $S Y D$ in FM initiation. Auxin enhances MP binding to BRM and SYD, which also bind the direct MP targets FIL, LFY, ANT, and TMO3 (Wu et al. 2015). Therefore, a chromatin switch model explains how binding of AUX/IAA proteins to MP at low auxin concentrations prevents the recruitment of SWI/SNF factors by MP, which instead binds to the TOPLESS (TPL) corepressor and HISTONE DEACETYLASE19 (HDA19), which promote a repressive chromatin state. Increasing auxin concentrations degrade AUX/ IAA proteins, enabling MP to recruit SWI/ SNF-containing complexes, which promote a permissive chromatin state that up-regulates MP targets (Table 1; Fig. 1; Wu et al. 2015).

\section{FLORAL ORGAN INITIATION}

Floral morphogenesis involves the perception of positional information within the FM by floral organ founder cells, to become specified, acquire a particular fate and outgrow. These processes 
M. Cucinotta et al.

Table 1. Summary of genes mentioned in the text

\begin{tabular}{|c|c|c|c|}
\hline Gene & $\begin{array}{c}\text { Protein function/relation with } \\
\text { auxin }\end{array}$ & $\begin{array}{c}\text { Floral developmental } \\
\text { context }\end{array}$ & References \\
\hline PIN-FORMED1 (PIN1) & Auxin efflux carrier & $\begin{array}{l}\text { Flower initiation }(\mathrm{FI}) \\
\quad \text { organ initiation }(\mathrm{OI})\end{array}$ & Okada et al. 1991 \\
\hline PINOID (PID) & $\begin{array}{l}\text { Kinase that regulates PIN1 } \\
\text { polarization }\end{array}$ & FI, OI & Bennett et al. 1995 \\
\hline ARF5/MONOPTEROS & $\begin{array}{l}\text { Auxin response factor (ARF), } \\
\text { transcription factor }(\mathrm{TF})\end{array}$ & $\begin{array}{l}\text { FI, organ boundaries } \\
\text { (OBs) OI, organ } \\
\text { growth }(\mathrm{OG})\end{array}$ & $\begin{array}{l}\text { Li et al. 2013; } \\
\text { Yamaguchi et al. } \\
2013\end{array}$ \\
\hline МАCCHI-BOU4 (MAB4) & Regulates PIN1 polarization & FI & Furutani et al. 2014 \\
\hline $\begin{array}{l}\text { DORNROESCHEN-LIKE } \\
\quad(D R N L)\end{array}$ & $\begin{array}{l}\text { AP2/ETHYLENE } \\
\text { RESPONSE FACTOR TF, a } \\
\text { floral-organ founder-cell } \\
\text { marker whose expression } \\
\text { precedes DR5 and } \\
\text { genetically interacts with } \\
\text { PID }\end{array}$ & FI, petal initiation & $\begin{array}{l}\text { Chandler et al. } \\
2011\end{array}$ \\
\hline $\begin{array}{l}\text { SHOOTMERISTEMLESS } \\
\quad(\text { STM })\end{array}$ & $\begin{array}{l}\text { KNOX TF, STM is repressed } \\
\text { by auxin }\end{array}$ & FI & Chung et al. 2019 \\
\hline ARF3/ETTIN (ETT) & $\mathrm{ARF}, \mathrm{TF}$ & $\begin{array}{l}\text { FI, gynoecium growth, } \\
\text { megaspore mother cell } \\
\text { (MMC), floral } \\
\text { meristem determinacy } \\
\text { (FMD) }\end{array}$ & $\begin{array}{l}\text { Sessions et al. } \\
\text { 1997; Chung } \\
\text { et al. } 2019\end{array}$ \\
\hline ARF4 & ARF, TF & FI & Chung et al. 2019 \\
\hline $\begin{array}{l}\text { FILAMENTOUS FLOWER } \\
\quad(\text { FIL })\end{array}$ & $\mathrm{TF}, F I L$ is activated by auxin & FI & Chung et al. 2019 \\
\hline BREVIPEDICELLUS (BP) & $\begin{array}{l}\text { KNOX TF, } B P \text { is repressed by } \\
\text { auxin }\end{array}$ & FI & Chung et al. 2019 \\
\hline $\begin{array}{l}\text { HISTONE DEACETYLASE19 } \\
\quad(\text { HDA19) }\end{array}$ & $\begin{array}{l}\text { Chromatin remodeling } \\
\text { factor, interacts with ETT } \\
\text { and ARF4 }\end{array}$ & FI & Chung et al. 2019 \\
\hline LEAFY & $\begin{array}{l}\text { Transcriptional master } \\
\text { regulator connected with } \\
\text { auxin maximum } \\
\text { maintenance, } L F Y \text { is } \\
\text { activated by MP }\end{array}$ & FI & $\begin{array}{l}\text { Weigel et al. 1992; } \\
\text { Li et al. 2013; } \\
\text { Yamaguchi et al. } \\
2013\end{array}$ \\
\hline AINTEGUMENTA (ANT) & $\begin{array}{l}\text { AP2-domain TF } \\
\text { transcriptionally up- } \\
\text { regulated by MP }\end{array}$ & FI, OI & $\begin{array}{l}\text { Yamaguchi et al. } \\
\text { 2013) }\end{array}$ \\
\hline $\begin{array}{l}\text { AINTEGUMENTA-LIKE6 } \\
\quad(\text { AIL6) }\end{array}$ & $\begin{array}{l}\text { AP2-domain TF } \\
\text { transcriptionally up- } \\
\text { regulated by MP }\end{array}$ & FI & $\begin{array}{l}\text { Yamaguchi et al. } \\
2013\end{array}$ \\
\hline IAA12/BODENLOS & $\begin{array}{l}\text { Aux/IAA protein that } \\
\text { interacts with MP }\end{array}$ & FI & $\begin{array}{l}\text { Yamaguchi et al. } \\
2013\end{array}$ \\
\hline TOPLESS (TPL) & $\begin{array}{l}\text { Corepressor of MP and ETT } \\
\text { targets }\end{array}$ & FI & Wu et al. 2015 \\
\hline$B R A M A(B R M)$ & $\begin{array}{l}\text { SWI/SNF ATPs chromatin } \\
\text { remodeling interactor of } \\
\text { MP }\end{array}$ & FI & Wu et al. 2015 \\
\hline
\end{tabular}

Continued 
Role of Auxin in Flower Development

Table 1. Continued

\begin{tabular}{|c|c|c|c|}
\hline Gene & $\begin{array}{l}\text { Protein function/relation with } \\
\text { auxin }\end{array}$ & $\begin{array}{c}\text { Floral developmental } \\
\text { context }\end{array}$ & References \\
\hline SPLAYED (SYD) & $\begin{array}{l}\text { SWI/SNF ATPs chromatin } \\
\text { remodeling interactor of } \\
\text { MP }\end{array}$ & FI & Wu et al. 2015 \\
\hline $\begin{array}{l}\text { TARGET OF } \\
\quad \text { MONOPTEROS3 (TMO3) }\end{array}$ & $\begin{array}{l}\text { AP2 TF transcriptionally up- } \\
\text { regulated by MP }\end{array}$ & FI, ovules & $\begin{array}{l}\text { Wu et al. 2015; } \\
\text { Cucinotta et al. } \\
2016\end{array}$ \\
\hline YUCCA $(Y U C)$ & $\begin{array}{l}\text { Flavin-monooxygenases that } \\
\text { catalyse IAA biosynthesis }\end{array}$ & FI, OI & Cheng et al. 2006 \\
\hline DORNROESCHEN (DRN) & $\begin{array}{l}\text { AP2/ETHYLENE } \\
\text { RESPONSE FACTOR that } \\
\text { genetically interacts with } \\
\text { PIN }\end{array}$ & FI, OI & $\begin{array}{c}\text { Chandler and } \\
\text { Werr } 2014\end{array}$ \\
\hline PUCHI & $\begin{array}{l}\text { AP2/ETHYLENE } \\
\text { RESPONSE FACTOR that } \\
\text { genetically interacts with } \\
\text { PID }\end{array}$ & FI, OI & $\begin{array}{c}\text { Chandler and } \\
\text { Werr } 2014\end{array}$ \\
\hline PERIANTHIA (PAN) & $\begin{array}{l}\text { bZIP TF that regulates YUC1 } \\
\text { and YUC4 }\end{array}$ & OB, petal initiation & Maier et al. 2011 \\
\hline PRESSED FLOWER (PRS) & $\begin{array}{l}\text { WUSCHEL-RELATED } \\
\text { HOMEOBOX, PRS } \\
\text { expression is induced by } \\
\text { auxin }\end{array}$ & Petal initiation & $\begin{array}{l}\text { Chandler and } \\
\text { Werr 2014; } \\
\text { Caggiano et al. } \\
2017\end{array}$ \\
\hline$A B C B 1 / 19$ & Auxin efflux carrier & FI, anther growth, pollen & $\begin{array}{l}\text { Zhao et al. 2013; } \\
\text { Cecchetti et al. } \\
2015\end{array}$ \\
\hline $\begin{array}{l}\text { CUP-SHAPED } \\
\quad \text { COTYLEDON (CUC) }\end{array}$ & $\begin{array}{l}\text { NAC-domain TFs regulated } \\
\text { by auxin, CUC function is } \\
\text { connected with polar auxin } \\
\text { transport (PAT) }\end{array}$ & OB, ovules & $\begin{array}{l}\text { Laufs et al. 2004; } \\
\text { Mallory et al. } \\
\text { 2005; Galbiati } \\
\text { et al. } 2013\end{array}$ \\
\hline RABBIT EARS (RBE) & $\begin{array}{l}\mathrm{C} 2 \mathrm{H} 2 \text { zinc finger protein } \\
\text { connection with PAT }\end{array}$ & OB, petal growth & $\begin{array}{l}\text { Lampugnani et al. } \\
2013\end{array}$ \\
\hline HANABA TARANU (HAN) & $\begin{array}{l}\text { GATA3-type transcriptional } \\
\text { repressor with a putative } \\
\text { role in PAT regulation }\end{array}$ & OB & Zhang et al. 2013 \\
\hline PETAL LOSS (PTL) & $\begin{array}{l}\text { Trihelix TF connected with } \\
\text { PAT }\end{array}$ & OB, petal growth & $\begin{array}{l}\text { Lampugnani et al. } \\
2013\end{array}$ \\
\hline$A U X 1$ & Auxin influx carrier & Petal growth & $\begin{array}{l}\text { Lampugnani et al. } \\
\quad 2013\end{array}$ \\
\hline SUPERMAN (SUP) & $\begin{array}{l}\mathrm{C} 2 \mathrm{H} 2 \text { zinc-finger protein that } \\
\text { represses YUC expression, } \\
\text { SUP is regulated by LFY }\end{array}$ & OB & $\begin{array}{l}\text { Sakai et al. } 1995 ; \\
\text { Xu et al. } 2018\end{array}$ \\
\hline $\begin{array}{c}\text { DEVELOPMENT-RELATED } \\
\text { MYB-LIKE1 (DRMY1) }\end{array}$ & $\begin{array}{l}\text { MYB-like TF that regulates } \\
\text { auxin response }\end{array}$ & Sepal outgrowth & Zhu et al. 2020 \\
\hline JAGGED (JAG) & $\begin{array}{l}\text { Zinc-finger protein that } \\
\text { regulates auxin response }\end{array}$ & Petal growth & $\begin{array}{l}\text { Dinneny et al. } \\
\text { 2004; Sauret- } \\
\text { Güeto et al. } 2013\end{array}$ \\
\hline ARGOS & $\begin{array}{l}\text { Auxin-inducible gene that } \\
\text { regulates ANT }\end{array}$ & Petal growth & Hu et al. 2003 \\
\hline
\end{tabular}


M. Cucinotta et al.

Table 1. Continued

\begin{tabular}{|c|c|c|c|}
\hline Gene & $\begin{array}{l}\text { Protein function/relation with } \\
\text { auxin }\end{array}$ & $\begin{array}{c}\text { Floral developmental } \\
\text { context }\end{array}$ & References \\
\hline BIGPETALP & $\begin{array}{l}\text { bHLH TF that interacts with } \\
\text { ARF8 }\end{array}$ & Petal growth & Varaud et al. 2011 \\
\hline ARF8 & $\mathrm{ARF}, \mathrm{TF}$ & $\begin{array}{l}\text { Petal growth, stamen } \\
\text { growth }\end{array}$ & $\begin{array}{l}\text { Nagpal et al. 2005; } \\
\text { Varaud et al. } \\
2011\end{array}$ \\
\hline ARF8.4 & $\mathrm{ARF}, \mathrm{TF}$ & Stamen growth & Ghelli et al. 2018 \\
\hline ARF6 & $\mathrm{ARF}, \mathrm{TF}$ & Stamen growth & Nagpal et al. 2005 \\
\hline SHORT INTERNODES (SHI) & $\begin{array}{l}\text { Zinc-finger TFs that regulate } \\
\text { auxin biosynthesis }\end{array}$ & Anther growth & $\begin{array}{l}\text { Estornell et al. } \\
2018\end{array}$ \\
\hline STYLISH1/2 (STY1/2) & $\begin{array}{l}\text { Zinc-finger TFs that regulate } \\
\text { auxin biosynthesis }\end{array}$ & $\begin{array}{l}\text { Anther growth, } \\
\text { gynoecium growth }\end{array}$ & $\begin{array}{l}\text { Trigueros et al. } \\
\text { 2009; Estornell } \\
\text { et al. } 2018\end{array}$ \\
\hline$T I R 1 / A F B$ & Nuclear auxin receptor & $\begin{array}{l}\text { Pollen, female } \\
\text { gametophyte (FG) }\end{array}$ & $\begin{array}{c}\text { Cecchetti et al. } \\
2008,2017\end{array}$ \\
\hline $\begin{array}{l}\text { DEFECTIVE IN ANTHER } \\
\text { DEHISCENCE1 (DAD1) }\end{array}$ & $\begin{array}{l}\text { Enzyme for JA biosynthesis } \\
\text { transcriptionally up- } \\
\text { regulated by ARF6/ARF8 }\end{array}$ & Anther dehiscence & $\begin{array}{l}\text { Nagpal et al. 2005; } \\
\text { Tabata et al. } \\
2010\end{array}$ \\
\hline MYB26 & $\begin{array}{l}\text { TF, MYB26 is induced by } \\
\text { ARF6/ARF8 }\end{array}$ & Anther dehiscence & Yang et al. 2017 \\
\hline ARF17 & ARF, TF & Anther dehiscence & Xu et al. 2019 \\
\hline MYB108 & $\begin{array}{l}\text { TF, } M Y B 108 \text { is } \\
\text { transcriptionally up- } \\
\text { regulated by ARF17 }\end{array}$ & Anther dehiscence & Xu et al. 2019 \\
\hline IAA19 & Aux/IAA protein & Anther dehiscence & $\begin{array}{l}\text { Tashiro et al. 2009; } \\
\text { Cecchetti et al. } \\
2017\end{array}$ \\
\hline AGAMOUS $(A G)$ & $\begin{array}{l}\text { MADS-box TF, regulates } \\
\text { YUC4 }\end{array}$ & FMD & $\begin{array}{l}\text { Liu et al. 2011, } \\
\text { 2014; } \\
\text { Yamaguchi et al. } \\
2018\end{array}$ \\
\hline WUSCHEL (WUS) & $\begin{array}{l}\text { Homeobox TF that controls } \\
\text { the stem-cell pool, } \\
\text { regulated by ETT }\end{array}$ & FMD & $\begin{array}{l}\text { Sun et al. 2009; Liu } \\
\text { et al. 2011; } \\
\text { Huang et al. } \\
2017\end{array}$ \\
\hline APETALA 2 (AP2) & $\begin{array}{l}\text { AP2/EREBP TF, negatively } \\
\text { regulates ETT }\end{array}$ & FMD & Liu et al. 2014 \\
\hline CRABS CLAW (CBR) & $\begin{array}{l}\text { YABBY TF that } \\
\text { transcriptionally up- } \\
\text { regulates TRN and YUC4 }\end{array}$ & FMD & $\begin{array}{l}\text { Yamaguchi et al. } \\
2018\end{array}$ \\
\hline TORNADO (TRN2) & $\begin{array}{l}\text { Tetraspanin protein that } \\
\text { regulates auxin } \\
\text { homeostasis }\end{array}$ & FMD & $\begin{array}{l}\text { Yamaguchi et al. } \\
2018\end{array}$ \\
\hline $\begin{array}{l}\text { CHROMATIN } \\
\text { REMODELING 11/17 } \\
\text { (CHR11/17) }\end{array}$ & $\begin{array}{l}\text { Recruited by AG to activate } \\
\quad Y U C\end{array}$ & FMD & $\begin{array}{l}\text { Yamaguchi et al. } \\
2018\end{array}$ \\
\hline KANADI1/4 (KAN1/4) & $\begin{array}{l}\text { GARP TF that interacts with } \\
\text { ETT }\end{array}$ & Gynoecium growth & Pekker et al. 2005 \\
\hline SPATULA (SPT) & bHLH TF that regulates PAT & Gynoecium growth & $\begin{array}{l}\text { Moubayidin and } \\
\text { Ostergaard } 2014\end{array}$ \\
\hline
\end{tabular}


Table 1. Continued

\begin{tabular}{|c|c|c|c|}
\hline Gene & $\begin{array}{l}\text { Protein function/relation with } \\
\text { auxin }\end{array}$ & $\begin{array}{c}\text { Floral developmental } \\
\text { context }\end{array}$ & References \\
\hline INDEHISCENT (IND) & bHLH TF that regulates PAT & Gynoecium growth & $\begin{array}{l}\text { Moubayidin and } \\
\text { Ostergaard } \\
\text { 2014; Kuhn } \\
\text { et al. } 2019\end{array}$ \\
\hline PIN-FORMED3 (PIN3) & Auxin efflux carrier & Gynoecium growth & Gremski et al. 2007 \\
\hline NGATHA (NGA3) & $\begin{array}{l}\text { RAV family TF that regulates } \\
\text { YUCs }\end{array}$ & Gynoecium growth & $\begin{array}{l}\text { Trigueros, et al. } \\
2009\end{array}$ \\
\hline $\begin{array}{l}\text { TOPLESS-RELATED2 } \\
\quad\left({ }^{*} \text { TPR } 2\right)\end{array}$ & Corepressor of ETT targets & Gynoecium growth & $\begin{array}{l}\text { Benjamins et al. } \\
\text { 2001; Gremski } \\
\text { et al. } 2007\end{array}$ \\
\hline HECATE $($ HEC) & bHLH TF that regulates PAT & Gynoecium growth & Gremski et al. 2007 \\
\hline
\end{tabular}

The gene or protein function and relationship to auxin is described in the second column, and the third column shows the specific developmental context within flower development with which these genes are involved. Genes whose proteins have a direct molecular link with auxin are shown in bold.

are associated with the establishment and maintenance of organ boundaries.

Expression of the synthetic auxin response reporters DR5::GFP and DII (van Mourik et al. 2012; Goldental-Cohen et al. 2017) demonstrate that auxin response maxima colocalize with sites of organ initiation. However, it is unclear whether auxin specifies floral organ founder cells, or merely activates outgrowth. Modeling of auxin responses (van Mourik et al. 2012) and the ABCE model of floral organ identity acquisition propose that concentric organ whorls are specified centripetally from outer to inner (Theißen and Saedler 2001). However, Arabidopsis floral body plan establishment is more complex and the DRNL founder-cell marker reveals biphasic development in which sepals initiate unidirectionally from the center of the IM, petals and lateral stamens arise from adjacent domains, and medial stamens initiate from a ring of $D R N L$ prepatterning (Chandler and Werr 2014). Expression of DRNL precedes auxin response maxima for some floral organs (Chandler et al. 2011) and the response of $D R N L$ to auxin remains enigmatic (Comelli et al. 2020). However, DRNL and its close relatives DRN and PUCHI redundantly determine numbers of all floral organs at the founder-cell level, partly cellnonautonomously (Table 1; Fig. 1; Chandler and Werr 2017). All three proteins integrate into auxin pathways: $D R N$ genetically interacts with pin 1, DRNL with pid, yuc1 and yuc4 (Chandler et al. 2011), and PUCHI with pid (Chandler and Werr 2014). PERIANTHIA (PAN) regulates the number of Arabidopsis perianth organs by targeting YUC-mediated auxin biosynthesis (Maier et al. 2011). The radially symmetrical arrangement of five perianth-whorl organs in pan (Running and Meyerowitz 1996) derives from bifurcations of sepal founder-cell populations at abaxial and adaxial positions and is partially dependent on PRESSED FLOWER (PRS) activity (Chandler and Werr 2014), which promotes cell proliferation in lateral floral primordium domains (Matsumoto 2001). In leaf primordia, auxin up-regulates $P R S$ and its paralogue WOX1 (Caggiano et al. 2017) via MP (Guan et al. 2017). Increased expression of DR5::GFP in the leaf base of prs wox 1 and the increased sensitivity of prs leaves to auxin transport inhibitors implies a role for PRS in auxin transport (Nakata et al. 2018). By analogy, positive feedback between auxin and PRS might exist during sepal initiation. Mutation of ETT also leads to one supernumerary petal and sepal (Sessions et al. 1997; Pekker et al. 2005).

\section{FLORAL ORGAN BOUNDARY ESTABLISHMENT}

Appropriate spatial positioning of floral organs requires the establishment and maintenance of 
M. Cucinotta et al.

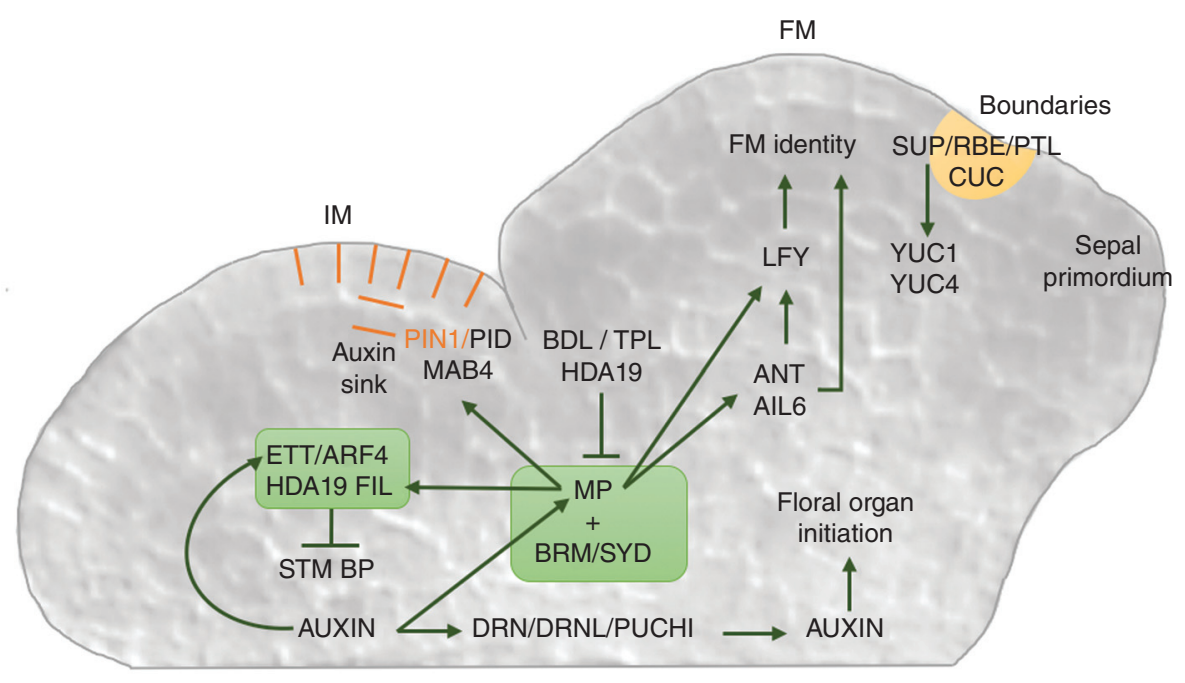

Figure 1. The gene regulatory networks involving auxin that regulate early floral meristem (FM) initiation and development. Schematic diagram of gene regulatory networks superimposed onto an image of an Arabidopsis FM emerging from the flank of the inflorescence meristem (IM), to illustrate how auxin coordinates FM initiation and identity and floral organ initiation (see text for details). (ANT) AINTEGUMENTA, (AIL6) AINTEGUMENTALIKE6, (ARF4) AUXIN RESPONSE FACTOR4, (BDL) BODENLOS, (BP) BREVIPEDICELLUS, (BRM) BRAHMA, (CUC) CUP-SHAPED COTYLEDON, (DRN) DORNRÖSCHEN, (DRNL) DORNRÖSCHENLIKE, (ETT) ETTIN, (FIL) FILAMENTOUS FLOWER, (HDA19) HISTONE DEACETYLASE19, (MAB4) MACCHI-BOU4, (PID) PINOID, (PIN1) PIN-FORMED1, (RBE) RABBIT EARS, (PTL) PETAL LOSS, (PYD) SPLAYED, (STM) SHOOTMERISTEMLESS, (SUP) SUPERMAN, (TPL) TOPLESS, (YUC1) YUCCA1, (YUC4) YUCCA4.

inter-organ boundary zones within floral whorls. In addition to separating organs, boundary domains act as organizing centers to developmentally pattern adjacent tissues. Many transcription factors have boundary functions that relate to auxin signaling ( $\mathrm{Yu}$ and Huang 2016). A boundary between the IM and FM ensures that the FM buttress separates from the IM. It involves polar auxin transport by ATP-BINDING-CASSETTE B19 (ABCB19) and in $a b c b 19$ mutants, auxin levels increase within the boundary (Zhao et al. 2013). Boundaries are zones of low auxin signaling (Wang et al. 2016), which repress cell division and expansion (Žádníková and Simon 2014; Wang et al. 2016).

The CUP-SHAPED COTYLEDON (CUC) genes CUC1, CUC2, and CUC3 are expressed in different floral organ boundaries (Takada et al. 2001; Hibara et al. 2006; Xu et al. 2008). Their combinatorial mutation leads to fused flo- ral organs (Laufs et al. 2004; Mallory et al. 2005) and CUC1 and CUC2 promote carpel margin meristem (CMM) initiation and positioning (Kamiuchi et al. 2014). Auxin represses CUC2 expression (Furutani et al. 2004), consistent with boundary domains having low auxin levels, high CUC levels, and repressed cell division. Developmental contexts such as cotyledon initiation, leaf serration formation, and ovule primordium initiation have suggested how CUC2 activate floral organ initiation in adjacent whorls, by up-regulating PIN1 expression to promote an auxin convergence point, which creates an auxin maximum where organ founder cells are specified (Vernoux et al. 2000; Furutani et al. 2004; Heisler et al. 2005; Bilsborough et al. 2011; Galbiati et al. 2013). The auxin maximum then represses CUC2 expression and restricts it to the boundary in a negative feedback loop (Vernoux et al. 2000; Bilsborough et al. 2011). 
Posttranscriptional regulation of CUC1 and CUC2 by three miRNA164 isoforms and mutation of MIR164c (also named EARLY EXTRA PETALS1 [EEP1]), leads to supernumerary petals and is associated with additional boundary domains in the second whorl (Baker et al. 2005). After petal primordium formation, MIR164c/ EEP1 expression is repressed in part by RABBIT EARS (RBE) (Huang et al. 2012), which also regulates sepal boundaries cell-non-autonomously. $R B E$ is also regulated by PETAL LOSS (PTL) in the intersepal zone, which establishes sepal boundaries concertedly with CUC1 and CUC2 (Lampugnani et al. 2013). HANABA TARANU (HAN) is expressed at organ boundaries and han mutants display fused sepals and fewer floral organs, which might be caused by impaired polar auxin transport by analogy to embryogenic HAN function, which regulates auxin flux to the hypophysis (Nawy et al. 2010; Zhang et al. 2013).

Auxin response within the intersepal boundary zone is controlled by PTL (Brewer 2004), which synergistically regulates petal initiation with RBE and PTL, illustrating that cell-nonautonomy is another important facet of auxin function (Griffith et al. 1999; Brewer 2004; Takeda et al. 2004; Krizek et al. 2006). In ptl mutants, petals arise sporadically and are absent in later-arising flowers (Griffith et al. 1999) and sites of petal initiation are restored by directing auxin synthesis within the intersepal zone (Lampugnani et al. 2013). Thus, auxin confers positional information for petal initiation by functioning as a mobile inter-whorl signal. RBE and PTL both function within the same pathway, with $R B E$ downstream of PTL. The petal defects of $p t l$ and rbe mutants are enhanced by mutation of the auxin influx carrier AUX1 (Lampugnani et al. 2013). Disruption of auxin efflux via PID and PIN1 in the petal initiation zone generally increases petal number, dependent on PTL function. $R B E$ also defines the second-whorl domain independently of $P T L$, by regulating several boundary genes (Fig. 2).

The SUPERMAN (SUP) C2H2 transcription factor, which is closely related to $R B E$ (Sakai et al. 1995), limits APETALA3 expression in whorl 4, and sup mutants produce supernumerary stamens (Bowman et al. 1992). SUP expression spans the whorl 3/4 boundary (Prunet et al. 2017) and reduces local auxin biosynthesis by directly binding to $Y U C 1$ and $Y U C 4$ and recruiting Polycomb-repressive complex 2 to repress their expression (Table 1; Fig. 2; Xu et al. 2018). This up-regulation of auxin biosynthesis in sup both expands the stem-cell domain between whorls 3 and 4 cell-non-autonomously and prolongs its activity (Xu et al. 2018), leading to supernumerary stamens as the fate of cells in whorl 4 changes from female to male (Prunet et al. 2017). In conclusion, the fine-tuning of auxin synthesis or activity in inter-organ or inter-whorl boundaries is one mechanism for controlling cell divisions and stem-cell availability for organ differentiation.

\section{FLORAL ORGAN OUTGROWTH}

The concentration of free auxin, indicated by DR5::GUS, is high in the tips of floral organ primordia in all whorls (Aloni et al. 2006), which drives rapid organ outgrowth. After the specification of sepal founder cells in a stereotypic order (Chandler and Werr 2014), sepal outgrowth in Arabidopsis is coordinated by DEVELOPMENT-RELATED MYB-LIKE1 (DRMY1) (Zhu et al. 2020). Coordinated auxin and cytokinin signaling regulates sepal outgrowth, analogous to the temporal regulation of FM outgrowth (Besnard et al.2014). drmy1 mutants display variable sepal sizes due to delayed outgrowth, which results from diffuse auxin and cytokinin response domains in sepal primordia. Wild-type DRMY1 signaling involves initial auxin responses in the outer primordium cell layer that encroach into the underlying cytokinin signaling domain. These localized and focused auxin and cytokinin signaling domains define regions of competency for outgrowth, in which DR5::GFP accumulates at the sepal tips and TCS at the base. In tomato, the MADS-box gene SIMBP21 negatively regulates sepal cell expansion, probably partly via auxinrelated pathways.

Auxin contributes to patterning petal shape and size, which depend on cell division during early development and cell expansion during 
M. Cucinotta et al.
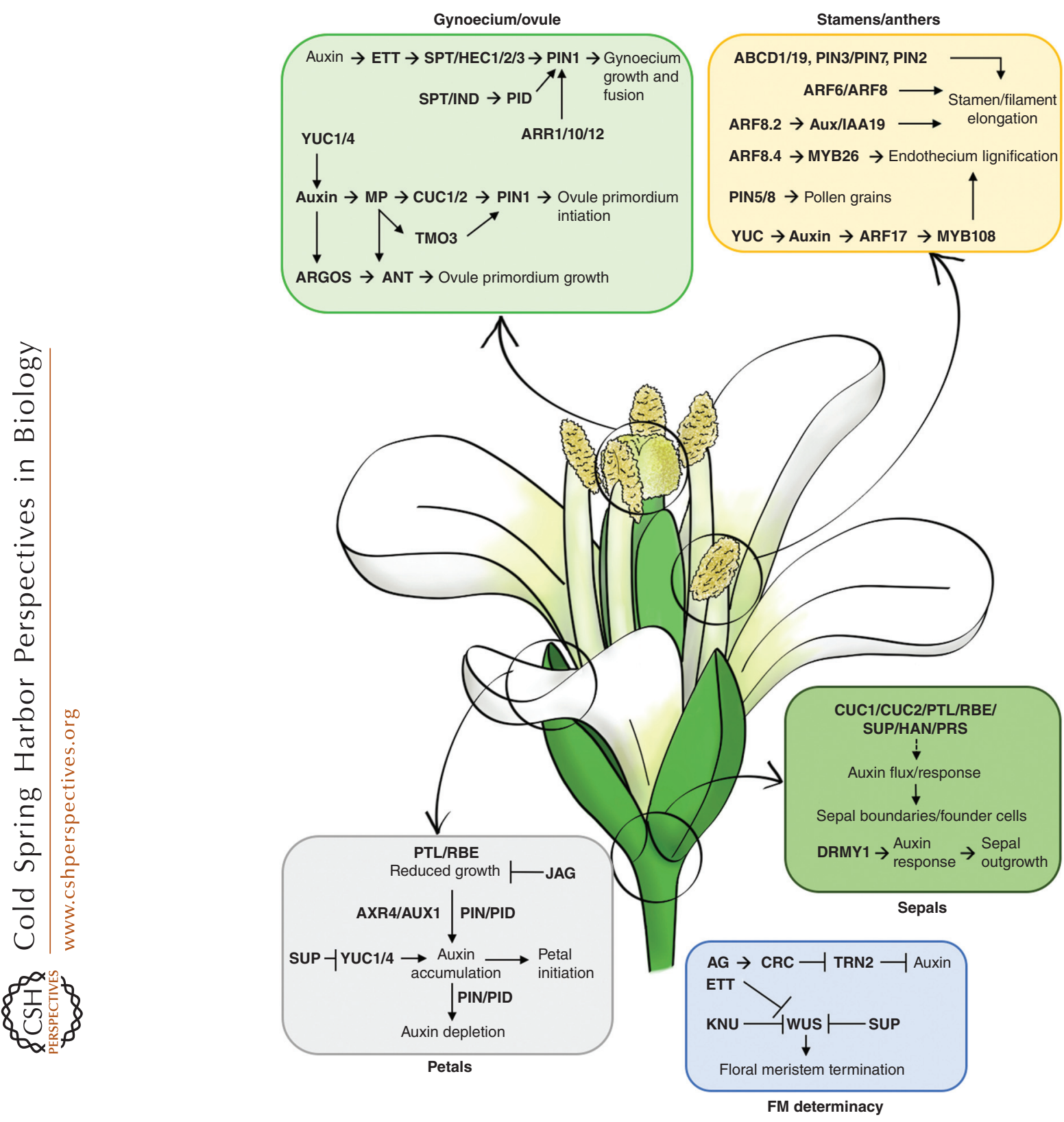

Figure 2. The gene regulatory networks involving auxin that orchestrate development of the different flower organs. A representation of an Arabidopsis flower linked to schematic diagrams to show how auxin integrates into the gene regulatory networks that coordinate gynoecium, stamen, petal, and sepal initiation and growth. An additional diagram shows the gene regulatory network involving auxin that relates to floral meristem (FM) determinacy and termination (see text for details). (AG) AGAMOUS, (ARF8/ARF17) AUXIN RESPONSE FACTOR7/17, (AUX1) AUXIN EFFLUX CARRIER1, (Aux/IAA19) AUX/IAA PROTEIN19, (AXR4) AUXIN-RESISTANT4, (CRC) CRABS CLAW, (DRMY1) DEVELOPMENT-RELATED MYB-LIKE1, (HAN) HANABA TARANU, (HEC1/HEC2/HEC3) HECATE1/2/3, (JAG) JAGGED, (KNU) KNUCKLES, (MYB26/ MYB108) MYB-DOMAIN PROTEIN26/08, (SPT) SPATULA, (TMO3) TARGET OF MONOPTEROS3, (TRN) TORNADO, (WUS) WUSCHEL (see additional abbreviations in Fig. 1). 
late development (Smyth et al. 1990). Many genes directly involved with auxin contribute to petal growth, including JAGGED (JAG), ARGOS, ANT, BIGPETALP (BPEp), and ARF8. JAG regulates growth by modulating the switch from cell proliferation to cell expansion (SauretGüeto et al. 2013). jag petals are narrow with a reduced distal region and a jagged or serrated margin (Dinneny et al. 2004). In jag, DR5::GFP expression is reduced, but is broader when JAG is ectopically expressed. Moreover, JAG directly represses PTL (Sauret-Güeto et al. 2013).

Overexpression of the auxin-inducible gene $A R G O S$ increases petal size by increasing the number and size of petal epidermal cells. This can be blocked by loss of ANT function, suggesting that ARGOS positively regulates ANT during petal organogenesis (Hu et al. 2003). Conversely, BPEp and ARF8 together regulate petal size by negatively affecting mitotic growth and restricting cell expansion during early and late petal development, respectively (Varaud et al. 2011), and arf8 and bpe mutants are associated with the up-regulation of early auxin-responsive genes. Notably, interaction between BPEp and ARF8 occurs via the BPEp carboxy-terminal domain, which shares sequence similarity with motif III of ARF and AUXIN/INDOLE-3-ACETIC ACID proteins (Varaud et al. 2011).

The stereotypic conical shape of cells in the Arabidopsis adaxial petal epidermis requires auxin signaling and apoplastic $\mathrm{pH}$ changes (Dang et al. 2020). Decreased auxin concentration, transport, or signaling abolishes cell-wall acidification and affects the height and shape of conical cells; notably, arf6-2 arf8-3 displays severe defects in conical cell shape and outgrowth (Tabata et al. 2010).

In Arabidopsis, stamens develop asynchronously: primordia of the four long medial stamens arise contemporaneously with petals during stage 5 of flower development, whereas the two short lateral stamens develop slightly later (Bowman et al. 1989). Reduction in auxin biosynthesis, especially by yuc 2 and yuc6 or polar transport ( $p i n 1$ and pid), reduces stamen number. The fewer-stamen phenotype of ett is enhanced by inhibiting auxin transport, leading to third-whorl organs that often consist of filamen- tous structures that lack anthers. Moreover, $A B C B / P G P$ genes that encode auxin efflux carriers are expressed in young stamen primordia, as well as in tapetum and pollen mother cells (PMCs) entering meiosis, and $a b c b 1$ and $a b c b 19$ show unsynchronized and precocious meiosis (Cecchetti et al. 2015).

The role of auxin during premeiotic phases of stamen development is poorly understood, partly because DR5 expression is only detected after microspore release (Cheng et al. 2006; Feng et al. 2006; Cecchetti et al. 2008, 2015). The R2D2 auxin reporter revealed that auxin-mediated DII depletion occurs in the locules early in anther development and overlaps with YUC1 and YUC4 activity (Cheng et al. 2006; Ståldal et al. 2012). Auxin biosynthesis is positively regulated by SHI/STY transcription factors, which are active throughout anther development and affect early anther patterning (Estornell et al. 2018).

Late stamen development involves the coordination of rapid filament elongation with anther dehiscence and pollen maturation and finally terminates with mature pollen-grain release. Anthers of $a b c b 1 a b c b 19$ overproliferate tapetum cells and show enhanced septum lignification, suggesting that auxin transport regulates cell division and lignification (Cecchetti et al. 2015). Inhibition of auxin efflux (Cecchetti et al. 2017) suggests that auxin flows from the tapetum to the middle layer, where auxin response maxima are important for coordinated pollen maturation and anther dehiscence.

Auxin signaling also represses precocious entry into subsequent developmental steps in several anther cell layers, and anthers of mutants in genes encoding the four TIR/AFB nuclear auxin receptors show premature dehiscence and pollen release compared to wild-type (Cecchetti et al. 2008, 2017). Mutations in ARF1, ARF2 (Ellis et al. 2005), ETT (Sessions et al. 1997), ARF4 (Pekker et al. 2005), ARF5 (Przemeck et al. 1996), ARF17 (Xu et al. 2019), ARF6, and ARF8 (Nagpal et al. 2005) all cause defects in male reproductive tissues. Stamens of arf6 arf8 are short with indehiscent anthers due to reduced jasmonic acid (JA) biosynthesis (Nagpal et al. 2005; Tabata et al. 2010). Furthermore, restriction of ARF6 and ARF8 domains by 
M. Cucinotta et al.

miR167 cleavage is required for anther development and fertility (Wu et al. 2006).

Several flower-specific, intron-retaining splice variants of ARF8 affect stamen development in Arabidopsis (Ghelli et al. 2018). ARF8.4 transcriptionally activates MYB26, which regulates secondary thickening and anther dehiscence (Yang et al. 2007, 2017), and ARF8.2 regulates JA biosynthesis by activating DAD1 to promote the final steps of anther dehiscence. The ARF17-MYB108 complex also regulates anther dehiscence in parallel with the ARF8.4MYB26 pathway (Xu et al. 2019). The stamenspecific AUX/IAA gene IAA19 controls filament elongation (Tashiro et al. 2009) and is regulated by auxin (Cecchetti et al. 2017). IAA19 is also regulated by ARF8.4, but is hardly affected by ARF8.2 and ARF8.1, highlighting the specificity of ARF8 isoforms during early stamen development (Table 1; Fig. 2; Ghelli et al. 2018).

\section{FLORAL MERISTEM DETERMINACY AND GYNOECIUM DEVELOPMENT}

The final floral development stage involves termination of FM growth following realization of the species-specific floral body plan. In Arabidopsis, the master regulator of FM determinacy, AGAMOUS (AG), represses the stem-cell marker WUS by recruiting Polycomb group (PcG) proteins to the WUS locus and in parallel, activating the expression of the WUS repressor KNUCKLES (KNU) (Sun et al. 2009; Liu et al. 2011). APETALA2 (AP2) antagonizes AG function by activating WUS expression (Huang et al. 2017). AG directly activates CRABS CLAW $(C R C)$, which represses TORNADO (TRN2), a regulator of auxin homeostasis, leading to a shift from meristem maintenance to organ differentiation (Yamaguchi et al. 2017). AG and CRC both activate the YUC4 promotor and AG recruits CHROMATIN REMODELING FACTOR11 and 17 (CHR11/17), which increases chromatin accessibility (Yamaguchi et al. 2018). Therefore, the regulation of auxin homeostasis by multiple pathways is an important component of FM determinacy (Table 1; Fig. 2).

The AG-AP2 FM determinacy pathway is also mediated by ETT. ETT and AG coordinate- ly repress WUS expression in the FM and combined loss of ETT and AG strongly enhances defects in FM indeterminacy. Moreover, ETT expression is indirectly positively regulated by AG. Binding of ETT to WUS is enhanced by AG activity, but independently from the WUS repression pathway mediated by KNU. In addition, ETT function in FM determinacy is negatively regulated by AP2 (Liu et al. 2014).

The appropriate termination of FM growth relates to gynoecium initiation in the FM center, which depletes the meristematic cell pool. The absence of a gynoecium in ag mutants indicates that FM determinacy is essential for female organ differentiation (Marsch-Martínez and de Folter 2016; Yamaguchi et al. 2017).

Gynoecium development involves the establishment of apical-basal and adaxial-abaxial axes. Mutation of ETT perturbs gynoecium organogenesis along the apical-basal axis, leading to reduced valve development and the ectopic expansion of transmitting tract and stigma (Sessions and Zambryski 1995; Alvarez and Smyth 1998). A long-standing model for gynoecium development along the apical-basal axis derived from observations that inhibition of auxin transport and auxin biosynthesis or transport mutants all generate a valveless gynoecium topped with stigmatic tissue. This suggests that a high local auxin biosynthesis at the gynoecium tip establishes a basipetally decreasing auxin morphogenetic gradient that specifies style, ovary, and gynophore (Nemhauser et al. 2000). However, DR5rev::GFP reports no auxin gradient, only auxin response maxima in carpel founder cells at stage 7 , the provasculature at stage 8 , apical tissue at stage 9 , and the vasculature and stigmatic papillae at stage 12 (Larsson et al. 2013). Additionally, specification of lateral and medial gynoecium domains, including valve outgrowth, depends on PIN1-mediated lateral auxin maxima (Larsson et al. 2014). A refined, so-called early action model (Hawkins and Liu 2014) based on early polarity establishment in lateral organs such as leaves, proposes that abaxial-adaxial polarity in early carpel primordia is critical for subsequent development. This is consistent with YUC1 and YUC4 activity at the start of organ initiation (Cheng et al. 2006), 
which potentially contributes to establishing an adaxial-abaxial boundary. Adaxial-abaxial axis formation also involves protein interactions between KANADI (KAN)1, KAN4, and ETT (Pekker et al. 2005). Therefore, gynoecium patterning involves two distinct phases: the early establishment of abaxial-adaxial identity within the mediolateral axis domains by coordinated auxin synthesis, transport, and signaling. Subsequently, this lateromedial domain is a prerequisite for establishing an apical-basal axis (Hawkins and Liu 2014).

During late gynoecium development, two additional foci of auxin response maxima initiate in the medial domain in addition to two in the lateral domain in the gynoecium apex. Immediately preceding style development, these four foci fuse into a ring due to SPATULA (SPT)/INDEHISCENT (IND)-dependent rearrangement of PIN proteins, which involves the direct repression of PID and leads to the acquisition of radial symmetry (Moubayidin and Østergaard 2014). During style and gynoecium development, auxin promotes the function of an ETT-IND complex that also leads to PID repression and finely regulates PIN localization and auxin flux (Moubayidin and Østergaard 2017; Kuhn et al. 2019). As well as interaction with IND, SPT associates with HECATE to regulate PIN1 and PIN3 expression and block cytokinin signaling (Gremski et al. 2007).

Because auxin biosynthesis mutants still differentiate stigmatic tissue, late gynoecium development is probably independent from the early action model and dependent on local auxin synthesis via YUC expression activated by STYLISH1/2 and NGA3 transcription factors in the gynoecium tip (Sohlberg et al. 2006; Trigueros et al. 2009; Eklund et al. 2011). SQUAMOSA PROMOTER-BINDING PROTEIN-LIKE transcription factors also contribute to style, septum, and transmitting tract development, probably upstream of YUC4 and by interactions with CRC, ETT, SPT, and STY1, which are all involved in auxin homeostasis or responsiveness (Xing et al. 2013).

The direct binding of auxin to the carboxyterminal domain of ETT (Kuhn et al. 2020) reveals an additional layer of auxin regulation that triggers a rapid and reversible switch of chromatin states during gynoecium development. ETT cannot interact with Aux/IAA proteins or mediate canonical auxin signaling because it lacks a PB1 domain. In low-auxin conditions, the ETT EAR repressor motif physically interacts with members of the TPL and TPL-RELATED (TPR) family of corepressors, which recruit histone deacetylase HDA19 to maintain chromatin of ETT targets in the gynoecium, such as PID (Benjamins et al. 2001) and HECATE1 (HEC1) (Gremski et al. 2007) in a repressed state. At higher auxin levels, binding of IAA to ETT causes its dissociation from TPL/TPR2, which prevents HDA19 from deacetylating histones at ETT target loci and leads to their transcriptional activation.

\section{AUXIN AND OVULE DEVELOPMENT}

Auxin maintains the meristematic activity of the placenta and determines the sites of ovule initiation and ovule identity. In most auxin-related mutants, defects in CMM formation cause the reduction or absence of placental tissue and ovules (Cucinotta et al. 2014; Reyes-Olalde and de Folter 2019). In particular, auxin concentration maxima generated by PIN1 in the placenta determine sites of ovule primordium initiation (Benková et al. 2003; Ceccato et al. 2013; Galbiati et al. 2013). Placental PIN1 expression is promoted by cytokinins via transcription of the direct MP targets CYTOKININ RESPONSE FACTOR2/TARGET OF MONOPTEROS3 and CUC1/CUC2 (Galbiati et al. 2013; Cucinotta et al. 2016, 2020), and a lower PIN1 level in crf2 and cuc2-1 CUC1_RNAi mutants results in fewer ovule primordia. After ovule initiation, ANT promotes primordium cell proliferation and integument growth. Correct ANT expression is also controlled by auxin via MP and ARGOS (Hu et al. 2003; Galbiati et al. 2013).

Auxin is critical for the somatic-to-germline fate transition, and for downstream events of megasporogenesis and female gametophyte (FG) development. PIN1 also drives an auxin maximum in the nucellus at the ovule tip in the L1 surrounding the megaspore mother cell (MMC) (Benková et al. 2003; Ceccato et al. 
M. Cucinotta et al.

2013). ETT is a negative regulator of MMC identity and is expressed in central ovule regions, where it restricts WUS expression, similar to its role in the FM. In the nucellus, ETT expression is tightly regulated by TAS3 tasiRNA, and deregulation of its expression causes supernumerary MMCs (Su et al. 2017).

After MMC enlargement, meiosis generates four haploid megaspores, but only the functional megaspore undergoes three mitoses to form an FG consisting of seven cells of four distinct cell types. During megagametogenesis, auxin response is localized to the chalazal pole in the sporophytic tissues surrounding the FG (Lituiev et al. 2013). This suggested a model in which the auxin cell-non-autonomously indirectly affects cell specification within the gametophyte by functioning in sporophytic tissues (Lituiev et al. 2013). Auxin helps to pattern the micropylar pole of the FG where egg and synergid cells are located (Skinner and Sundaresan 2018), and loss of synergid identity and the occasional acquisition of egg identity results when TIR1 and ARFs are down-regulated or inactivated in the young FG (Panoli et al. 2015; Liu et al. 2018). Conversely, ectopic YUC expression shifts micropylar cell fates toward the chalazal end of the gametophyte, conferring synergid and egg-cell marker expression to the central cell and antipodal cells (Panoli et al. 2015). It remains unknown whether auxin influences mitosis and cell identity within the TM, which could be addressed by live imaging.

\section{CONCLUDING REMARKS}

Despite detailed understanding of how auxin integrates into the gene networks that regulate floral development, and major advances in characterizing components of the auxin response machinery, higher-order layers of complexity involved in auxin response continue to emerge. However, understanding how auxin confers positional information for organ initiation requires knowledge concerning spatiotemporal auxin responses at single-cell resolution. Despite the central role of MP in coordinating auxin responses, the complete genome-wide repertoire of direct ARF targets has not been captured and paradigmatic canonical auxin response signaling might involve as-yet-unknown ARF-binding sequences.

Most importantly, although Arabidopsis is the best-studied plant development model, its flowers are hardly representative of angiosperm floral diversity and the molecular-genetic basis of many features of floral development that underlie differences in the floral body plan and morphogenesis in other species have not been considered; some examples include the unidirectional organ initiation, the existence of overlapping temporal organ initiation in different whorl, and common primordia in many legumes (Ferrandiz et al. 1999; Tucker 2003; Benlloch et al. 2015) or flowers that show centripetal, centrifugal (or basipetal), or more chaotic sequences of organ development within a single flower or whorl (Rudall 2010). One recurring theme in floral development is how auxin gradients orchestrate aspects of floral development in concert with those in cytokinin. Despite the characterization of auxin signaling components in comparative species, this needs to be combined with studies on comparative floral morphology at a high spatiotemporal resolution, to identify evolutionarily conserved aspects of the regulation of floral development by auxin to be identified, and to elucidate further levels of complexity not evident in Arabidopsis.

\section{ACKNOWLEDGMENTS}

A.C. and L.C. were supported by Ministero dell'Istruzione, dell'Università e della Ricerca (MIUR). M.C., A.C., and L.C. were funded by MIUR-PRIN 2012. We thank Sara Comai for drawing the flower in Figure 2.

\section{REFERENCES}

\footnotetext{
Aloni R, Aloni E, Langhans M, Ullrich CI. 2006. Role of auxin in regulating Arabidopsis flower development. Planta 223: 315-328. doi:10.1007/s00425-005-0088-9

Alonso JM, Stepanova AN, Leisse TJ, Kim CJ, Chen H, Shinn P, Stevenson DK, Zimmerman J, Barajas P, Cheuk R, et al. 2003. Genome-wide insertional mutagenesis of Arabidopsis thaliana. Science 301: 653-657. doi:10.1126/sci ence.1086391
} 
Alvarez J, Smyth DR. 1998. Genetic pathways controlling carpel development in Arabidopsis thaliana. J Plant Res 111: 295-298. doi:10.1007/BF02512187

Alvarez-Buylla ER, Benítez M, Corvera-Poiré A, Cador C, De Folter S, De Buen AG, Garay-Arroyo A, García-Ponce B, Jaimes-Miranda F, Rigoberto V, et al. 2010. Flower development. Arabidopsis Book 8: e0127. doi:10.1199/tab.0127

Baker CC, Sieber P, Wellmer F, Meyerowitz EM. 2005. The early extra petals 1 mutant uncovers a role for microRNA miR164c in regulating petal number in Arabidopsis. Curr Biol 15: 303-315. doi:10.1016/j.cub.2005.02.017

Benjamins R, Quint A, Weijer D, Hooykaas P, Offringa R. 2001. The PINOID protein kinase regulates organ development in Arabidopsis by enhancing polar auxin transport. Development 128: 4057-4067.

Benková E, Michniewicz M, Sauer M, Teichmann T, Seifertová D, Jürgens G, Friml J. 2003. Local, efflux-dependent auxin gradients as a common module for plant organ formation. Cell 115: 591-602. doi:10.1016/S0092-8674 (03)00924-3

Benlloch R, Berbel A, Ali L, Gohari G, Millán T, Madueño F. 2015. Genetic control of inflorescence architecture in legumes. Front Plant Sci 6: 543. doi:10.3389/fpls.2015 .00543

Bennett SRM, Alvarez J, Bossinger G, Smyth DR. 1995. Morphogenesis in pinoid mutants of Arabidopsis thaliana. Plant J 8: 505-520. doi:10.1046/j.1365-313X.1995 .8040505.x

Besnard F, Refahi Y, Morin V, Marteaux B, Brunoud G, Chambrier P, Rozier F, Mirabet V, Legrand J, Lainé S, et al. 2014. Cytokinin signalling inhibitory fields provide robustness to phyllotaxis. Nature 505: 417-421. doi:10 .1038/nature12791

Bilsborough GD, Runions A, Barkoulas M, Jenkins HW, Hasson A, Galinha C, Laufs P, Hay A, Prusinkiewicz P, Tsiantis M. 2011. Model for the regulation of Arabidopsis thaliana leaf margin development. Proc Natl Acad Sci 108: 3424-3429. doi:10.1073/pnas.1015162108

Bowman JL, Smyth DR, Meyerowitz EM. 1989. Genes directing flower development in Arabidopsis. Plant Cell 1: 37-52.

Bowman JL, Sakai H, Jack T, Weigel D, Mayer U, Meyerowitz EM. 1992. SUPERMAN a regulator of floral homeotic genes in Arabidopsis. Development 114: 599-615.

Brewer PB. 2004. PETAL LOSS, a trihelix transcription factor gene, regulates perianth architecture in the Arabidopsis flower. Development 131: 4035-4045. doi:10.1242/dev .01279

Caggiano MP, Yu X, Bhatia N, Larsson A, Ram H, Ohno CK, Sappl P, Meyerowitz EM, Jönsson H, Heisler MG. 2017. Cell type boundaries organize plant development. eLife 6: e27421. doi:10.7554/eLife.27421

Ceccato L, Masiero S, Sinha Roy D, Bencivenga S, Roig-Villanova I, Ditengou FA, Palme K, Simon R, Colombo L. 2013. Maternal control of PIN1 is required for female gametophyte development in Arabidopsis. PLoS ONE 8: e66148. doi:10.1371/journal.pone.0066148

Cecchetti V, Altamura MM, Falasca G, Costantino P, Cardarelli M. 2008. Auxin regulates Arabidopsis anther dehiscence, pollen maturation, and filament elongation. Plant Cell 20: 1760-1774. doi:10.1105/tpc.107.057570
Cecchetti V, Brunetti P, Napoli N, Fattorini L, Altamura MM, Costantino P, Cardarelli M. 2015. ABCB1 and ABCB19 auxin transporters have synergistic effects on early and late Arabidopsis anther development. J Integr Plant Biol 57: 1089-1098. doi:10.1111/jipb.12332

Cecchetti V, Celebrin D, Napoli N, Ghelli R, Brunetti P, Costantino P, Cardarelli M. 2017. An auxin maximum in the middle layer controls stamen development and pollen maturation in Arabidopsis. New Phytol 213: 1194-1207. doi:10.1111/nph.14207

Chandler JW. 2011. Founder cell specification. Trends Plant Sci. 16: 607-613. doi:10.1016/j.tplants.2011.08.005

Chandler JW, Werr W. 2014. Arabidopsis floral phytomer development: auxin response relative to biphasic modes of organ initiation. J Exp Bot 65: 3097-3110. doi:10.1093/ $\mathrm{jxb} / \mathrm{eru} 153$

Chandler J, Werr W. 2017. DORNRÖSCHEN, DORNRÖSCHEN-LIKE, and PUCHI redundantly control floral meristem identity and organ initiation in Arabidopsis. J Exp Bot 68: 3457-3472. doi:10.1093/jxb/erx208

Chandler JW, Cole M, Jacobs B, Comelli P, Werr W. 2011. Genetic integration of DORNRÖSCHEN and DORNRÖSCHEN-LIKE reveals hierarchical interactions in auxin signalling and patterning of the Arabidopsis apical embryo. Plant Mol Biol 75: 223-236. doi:10.1007/s11103010-9721-5

Cheng Y, Dai X, Zhao Y. 2006. Auxin biosynthesis by the YUCCA flavin monooxygenases controls the formation of floral organs and vascular tissues in Arabidopsis. Genes Dev 20: 1790-1799. doi:10.1101/gad.1415106

Chung Y, Zhu Y, Wu MF, Simonini S, Kuhn A, ArmentaMedina A, Jin R, Østergaard L, Gillmor CS, Wagner D. 2019. Auxin response factors promote organogenesis by chromatin-mediated repression of the pluripotency gene SHOOTMERISTEMLESS. Nat Commun 10: 886.

Cole M, Chandler J, Weijers D, Jacobs B, Comelli P, Werr W. 2009. DORNROSCHEN is a direct target of the auxin response factor MONOPTEROS in the Arabidopsis embryo. Development 136: 1643-1651. doi:10.1242/dev .032177

Comelli P, Glowa D, Frerichs A, Engelhorn J, Chandler JW, Werr W. 2020. Functional dissection of the DORNRÖSCHEN-LIKE enhancer 2 during embryonic and phyllotactic patterning. Planta 251: 90. doi:10.1007/s00425020-03381-7

Cucinotta M, Colombo L, Roig-villanova I. 2014. Ovule development, a new model for lateral organ formation. Front Plant Sci 5: 1-12. doi:10.3389/fpls.2014.00117

Cucinotta M, Manrique S, Guazzotti A, Quadrelli NE, Mendes MA, Benkova E, Colombo L. 2016. Cytokinin response factors integrate auxin and cytokinin pathways for female reproductive organ development. Development 143: 4419-4424. doi:10.1242/dev.143545

Cucinotta M, Di Marzo M, Guazzotti A, de Folter S, Kater MM, Colombo L. 2020. Gynoecium size and ovule number are interconnected traits that impact seed yield. J Exp Bot 71: 2479-2489. doi:10.1093/jxb/eraa050

Dang X, Chen B, Liu F, Ren H, Liu X, Zhou J, Qin J, Lin D. 2020. Auxin signaling-mediated apoplastic $\mathrm{pH}$ modification functions in petal conical cell shaping. Cell Rep 30: 3904-3916.e3. doi:10.1016/j.celrep.2020.02.087 
M. Cucinotta et al.

Dinneny JR, Yadegari R, Fischer RL, Yanofsky MF, Weigel D. 2004. The role of JAGGED in shaping lateral organs. Development 131: 1101-1110. doi:10.1242/dev.00949

Eklund DM, Cierlik I, Ståldal V, Claes AR, Vestman D, Chandler J, Sundberg E. 2011. Expression of Arabidopsis SHORT INTERNODES/STYLISH family genes in auxin biosynthesis zones of aerial organs is dependent on a GCC box-like regulatory element. Plant Physiol 157: 2069-2080. doi:10.1104/pp.111.182253

Ellis CM, Nagpal P, Young JC, Hagen G, Guilfoyle TJ, Reed JW. 2005. AUXIN RESPONSE FACTOR1 and AUXIN RESPONSE FACTOR2 regulate senescence and floral organ abscission in Arabidopsis thaliana. Development 132: 4563-4574. doi:10.1242/dev.02012

Estornell LH, Landberg K, Cierlik I, Sundberg E. 2018. SHI/ STY genes affect pre- and post-meiotic anther processes in auxin sensing domains in Arabidopsis. Front Plant Sci 9: 150. doi:10.3389/fpls.2018.00150

Feng XL, Ni WM, Elge S, Mueller-Roeber B, Xu ZH, Xue HW. 2006. Auxin flow in anther filaments is critical for pollen grain development through regulating pollen mitosis. Plant Mol Biol 61: 215-226. doi:10.1007/s11103006-0005-z

Ferrandiz C, Navarro C, Gomez MD, Canas LA, Beltran JP. 1999. Flower development in Pisum sativum: from the war of the whorls to the battle of the common primordia. Dev Genet 25: 280-290.

Frerichs A, Thoma R, Abdallah AT, Frommolt P, Werr W, Chandler JW. 2016. The founder-cell transcriptome in the Arabidopsis apetala1 cauliflower inflorescence meristem. BMC Genomics 17: 855. doi:10.1186/s12864-0163189-x

Furutani M, Vernoux T, Traas J, Kato T, Tasaka M, Aida M. 2004. PIN-FORMED1 and PINOID regulate boundary formation and cotyledon development in Arabidopsis embryogenesis. Development 131: 5021-5030. doi:10 $.1242 / \mathrm{dev} .01388$

Furutani M, Nakano Y, Tasaka M. 2014. MAB4-induced auxin sink generates local auxin gradients in Arabidopsis organ formation. Proc Natl Acad Sci 111: 1198-1203. doi:10.1073/pnas.1316109111

Galbiati F, Sinha Roy D, Simonini S, Cucinotta M, Ceccato L, Cuesta C, Simaskova M, Benková E, Kamiuchi Y, Aida M, et al. 2013. An integrative model of the control of ovule primordia formation. Plant J 76: 446-455. doi:10.1111/ tpj.12309

Galvan-Ampudia CS, Cerutti G, Legrand J, et al. 2020. Temporal integration of auxin information for the regulation of patterning. eLife 9: e55832.

Gälweiler L, Guan C, Müller A, Wisman E, Mendgen K, Yephremov A, Palme K. 1998. Regulation of polar auxin transport by AtPIN1 in Arabidopsis vascular tissue. Sci 282: 2226-2230. doi:10.1126/science.282.5397.2226

Ghelli R, Brunetti P, Napoli N, De Paolis A, Cecchetti V, Tsuge T, Serino G, Matsui M, Mele G, Rinaldi G, et al 2018. A newly identified flower-specific splice variant of AUXIN RESPONSE FACTOR8 regulates stamen elongation and endothecium lignification in Arabidopsis. Plant Cell 30: 620-637. doi:10.1105/tpc.17.00840

Goldental-Cohen S, Israeli A, Ori N, Yasuor H. 2017. Auxin response dynamics during wild-type and entire flower development in tomato. Plant Cell Physiol 58: 16611672. doi:10.1093/pcp/pcx102

Gremski K, Ditta G, Yanofsky MF. 2007. The HECATE genes regulate female reproductive tract development in Arabidopsis thaliana. Development 134: 3593-3601. doi: $10.1242 /$ dev. 011510

Griffith ME, da Silva Conceição A, Smyth DR. 1999. PETAL LOSS gene regulates initiation and orientation of second whorl organs in the Arabidopsis flower. Development 126: 5635-5644.

Guan C, Wu B, Yu T, Wang Q, Krogan NT, Liu X, Jiao Y. 2017. Spatial auxin signaling controls leaf flattening in Arabidopsis. Curr Biol 27: 2940-2950.e4. doi:10.1016/j .cub.2017.08.042

Hawkins C, Liu Z. 2014. A model for an early role of auxin in Arabidopsis gynoecium morphogenesis. Front Plant Sci 5: 327.

Heisler MG, Ohno C, Das P, Sieber P, Reddy GV, Long JA, Meyerowitz EM. 2005. Patterns of auxin transport and gene expression during primordium development revealed by live imaging of the Arabidopsis inflorescence meristem. Curr Biol 15: 1899-1911. doi:10.1016/j.cub .2005 .09 .052

Hibara K, Karim MR, Takada S, Taoka K, Furutani M, Aida M, Tasaka M. 2006. Arabidopsis CUP-SHAPED COTY$L E D O N 3$ regulates postembryonic shoot meristem and organ boundary formation. Plant Cell 18: 2946-2957. doi:10.1105/tpc.106.045716

Hu Y, Xie Q, Chua NH. 2003. The Arabidopsis auxin-inducible gene ARGOS controls lateral organ size. Plant Cell 15: 1951-1961. doi:10.1105/tpc.013557

Huang T, López-Giráldez F, Townsend JP, Irish VF. 2012. RBE controls microRNA164 expression to effect floral organogenesis. Dev 139: 2161-2169. doi:10.1242/dev .075069

Huang Z, Shi T, Zheng B, Yumul RE, Liu X, You C, Gao Z, Xiao L, Chen X. 2017. APETALA2 antagonizes the transcriptional activity of AGAMOUS in regulating floral stem cells in Arabidopsis thaliana. New Phytol 215: 1197-1209. doi:10.1111/nph.14151

Irish VF. 2010. The flowering of Arabidopsis flower development. Plant J 61: 1014-1028. doi:10.1111/j.1365-313X .2009.04065.x

Kamiuchi Y, Yamamoto K, Furutani M, Tasaka M, Aida M. 2014. The CUC1 and CUC2 genes promote carpel margin meristem formation during Arabidopsis gynoecium development. Front Plant Sci 5: 165. doi:10.3389/fpls.2014 .00165

Krizek BA, Lewis MW, Fletcher JC. 2006. RABBIT EARS is a second-whorl repressor of AGAMOUS that maintains spatial boundaries in Arabidopsis flowers. Plant $J$ 45: 369-383. doi:10.1111/j.1365-313X.2005.02633.x

Kuhn A, Runciman B, Tasker-Brown W, Østergaard L. 2019. Two auxin response elements fine-tune PINOID expression during gynoecium development in Arabidopsis thaliana. Biomolecules 9: 526. doi:10.3390/biom9100526

Kuhn A, Ramans Harborough S, McLaughlin HM, Natarajan B, Verstraeten I, Friml J, Kepinski S, Østergaard L. 2020. Direct ETTIN-auxin interaction controls chromatin states in gynoecium development. eLife 9: e51787. doi:10.7554/eLife.51787 
Kwiatkowska D. 2008. Flowering and apical meristem growth dynamics. J Exp Bot 59: 187-201. doi:10.1093/ jxb/erm 290

Lampugnani ER, Kilinc A, Smyth DR. 2013. Auxin controls petal initiation in Arabidopsis. Development 140: 185194. doi:10.1242/dev. 084582

Larsson E, Franks RG, Sundberg E. 2013. Auxin and the Arabidopsis thaliana gynoecium. J Exp Bot 64: 26192627. doi:10.1093/jxb/ert099

Larsson E, Roberts CJ, Claes R, Franks RG, Sundberg E. 2014. Polar auxin transport is essential for medial versus lateral tissue specification and vascular-mediated valve outgrowth in Arabidopsis gynoecia. Plant Physiol 166 1998-2012. doi:10.1104/pp.114.245951

Laufs P, Peaucelle A, Morin H, Traas J. 2004. MicroRNA regulation of the CUC genes is required for boundary size control in Arabidopsis meristems. Development 131: 4311-4322. doi:10.1242/dev.01320

Li W, Zhou Y, Liu X, Yu P, Cohen JD, Meyerowitz EM. 2013. LEAFY controls auxin response pathways in floral primordium formation. Sci Signal 6: ra23.

Lituiev DS, Krohn NG, Muller B, Jackson D, Hellriegel B, Dresselhaus T, Grossniklaus U. 2013. Theoretical and experimental evidence indicates that there is no detectable auxin gradient in the angiosperm female gametophyte. Development 140: 4544-4553. doi:10.1242/dev .098301

Liu X, Kim YJ, Müller R, Yumul RE, Liu C, Pan Y, Cao X, Goodrich J, Chen X. 2011. AGAMOUS terminates floral stem cell maintenance in Arabidopsis by directly repressing WUSCHEL through recruitment of Polycomb Group proteins. Plant Cell 23: 3654-3670. doi:10.1105/tpc.111 .091538

Liu X, Dinh TT, Li D, Shi B, Li Y, Cao X, Guo L, Pan Y, Jiao Y, Chen X. 2014. AUXIN RESPONSE FACTOR 3 integrates the functions of AGAMOUS and APETALA2 in floral meristem determinacy. Plant J 80: 629-641. doi:10 $.1111 /$ tpj. 12658

Liu Z, Miao L, Huo R, Song X, Johnson C, Kong L, Sundaresan V, Yu X. 2018. ARF2-ARF4 and ARF5 are essential for female and male gametophyte development in Arabidopsis. Plant Cell Physiol 59: 179-189. doi:10.1093/pcp/ pcx174

Ma Y, Miotk A, Šutiković Z, Ermakova O, Wenzl C, Medzihradszky A, Gaillochet C, Forner J, Utan G, Brackmann $\mathrm{K}$, et al. 2019. WUSCHEL acts as an auxin response rheostat to maintain apical stem cells in Arabidopsis. Nat Commun 10: 5093

Maier AT, Stehling-Sun S, Offenburger SL, Lohmann JU. 2011. The bZIP transcription factor PERIANTHIA: multifunctional hub for meristem control. Front Plant Sci 2: 79. doi:10.3389/fpls.2011.00079

Mallory AC, Bartel DP, Bartel B. 2005. MicroRNA-directed regulation of Arabidopsis AUXIN RESPONSE FACTOR17 is essential for proper development and modulates expression of early auxin response genes. Plant Cell 17: 1360-1375. doi:10.1105/tpc.105.031716

Marsch-Martínez N, de Folter S. 2016. Hormonal control of the development of the gynoecium. Curr Opin Plant Biol 29: 104-114. doi:10.1016/j.pbi.2015.12.006

Matsumoto N. 2001. A homeobox gene, PRESSED FLOWER, regulates lateral axis-dependent development of Ara- bidopsis flowers. Genes Dev 15: 3355-3364. doi:10.1101/ gad.931001

Moubayidin L, Østergaard L. 2014. Dynamic control of auxin distribution imposes a bilateral-to-radial symmetry switch during gynoecium development. Curr Biol 24: 2743-2748. doi:10.1016/j.cub.2014.09.080

Moubayidin L, Østergaard L. 2017. Gynoecium formation: an intimate and complicated relationship. Curr Opin Genet Dev 45: 15-21. doi:10.1016/j.gde.2017.02.005

Nagpal P, Ellis CM, Weber H, Ploense SE, Barkawi LS, Guilfoyle TJ, Hagen G, Alonso JM, Cohen JD, Farmer EE, et al. 2005. Auxin response factors ARF6 and ARF8 promote jasmonic acid production and flower maturation. Development 132: 4107-4118. doi:10.1242/dev.01955

Nakata MT, Tameshige T, Takahara M, Mitsuda N, Okada K. 2018. The functional balance between the WUSCHELRELATED HOMEOBOX1 gene and the phytohormone auxin is a key factor for cell proliferation in Arabidopsis seedlings. Plant Biotechnol 35: 141-154. doi:10.5511/ plantbiotechnology.18.0427a

Nawy T, Bayer M, Mravec J, Friml J, Birnbaum KD, Lukowitz W. 2010. The GATA factor HANABA TARANU is required to position the proembryo boundary in the early Arabidopsis embryo. Dev Cell 19: 103-113. doi:10.1016/j devcel.2010.06.004

Nemhauser JL, Feldman LJ, Zambryski PC. 2000. Auxin and ETTIN in Arabidopsis gynoecium morphogenesis. Development 127: 3877-3888

Okada K, Ueda J, Komaki MK, Bell CJ, Shimura Y. 1991. Requirement of the auxin polar transport system in early stages of Arabidopsis floral bud formation. Plant Cell 3: 677-684. doi:10.2307/3869249

Panoli A, Martin MV, Alandete-Saez M, Simon M, Neff C, Swarup R, Bellido A, Yuan L, Pagnussat GC, Sundaresan V. 2015. Auxin import and local auxin biosynthesis are required for mitotic divisions, cell expansion and cell specification during female gametophyte development in Arabidopsis thaliana. PLoS ONE 10: e0126164. doi:10 .1371/journal.pone.0126164

Pekker I, Alvarez JP, Eshed Y. 2005. Auxin response factors mediate Arabidopsis organ asymmetry via modulation of KANADI activity. Plant Cell 17: 2899-2910. doi:10.1105/ tpc. 105.034876

Prunet N, Yang W, Das P, Meyerowitz EM, Jack TP. 2017. SUPERMAN prevents class B gene expression and promotes stem cell termination in the fourth whorl of Arabidopsis thaliana flowers. Proc Natl Acad Sci 114: 7166 7171. doi:10.1073/pnas.1705977114

Przemeck GH, Mattsson J, Hardtke C, Sung ZR, Berleth T. 1996. Studies on the role of the Arabidopsis gene MONOPTEROS in vascular development and plant cell axialization. Planta 200: 229-237. doi:10.1007/BF00208313

Reinhardt D, Mandel T, Kuhlemeier C. 2000. Auxin regulates the initiation and radial position of plant lateral organs. Plant Cell 12: 507-518. doi:10.1105/tpc.12.4.507

Reyes-Olalde JI, de Folter S. 2019. Control of stem cell activity in the carpel margin meristem (CMM) in Arabidopsis. Plant Reprod 32: 123-136. doi:10.1007/s00497-01800359-0

Rudall PJ. 2010. All in a spin: centrifugal organ formation and floral patterning. Curr Opin Plant Biol 13: 108-114. doi:10.1016/j.pbi.2009.09.019 
Running MP, Meyerowitz EM. 1996. Mutations in the PERIANTHIA gene of Arabidopsis specifically alter floral organ number and initiation pattern. Development 122: 1261-1269.

Sakai H, Medrano LJ, Meyerowitz EM. 1995. Role of SUPERMAN in maintaining Arabidopsis floral whorl boundaries. Nature 378: 199-203. doi:10.1038/378199a0

Sauret-Güeto S, Schiessl K, Bangham A, Sablowski R, Coen E. 2013. JAGGED controls Arabidopsis petal growth and shape by interacting with a divergent polarity field. PLoS Biol 11: e1001550. doi:10.1371/journal.pbio.1001550

Sessions RA, Zambryski PC. 1995. Arabidopsis gynoecium structure in the wild type and in ettin mutants. Development 121: 1519-1532.

Sessions RA, Nemhauser JL, McColl A, Roe JL, Feldmann KA, Zambryski PC. 1997. ETTIN patterns the Arabidopsis floral meristem and reproductive organs. Development 124: 4481-4491.

Skinner DJ, Sundaresan V. 2018. Recent advances in understanding female gametophyte development. F1000Res 7: 804. doi:10.12688/f1000research.14508.1

Smyth DR, Bowman JL, Meyerowitz EM. 1990. Early flower development in Arabidopsis. Plant Cell 2: 755-767.

Sohlberg JJ, Myrenås M, Kuusk S, Lagercrantz U, Kowalczyk M, Sandberg G, Sundberg E. 2006. STY1 regulates auxin homeostasis and affects apical-basal patterning of the Arabidopsis gynoecium. Plant J 47: 112-123. doi:10 $.1111 /$ j.1365-313X.2006.02775.x

Ståldal V, Cierlik I, Chen S, Landberg K, Baylis T, Myrenås M, Sundström JF, Eklund DM, Ljung K, Sundberg E. 2012. The Arabidopsis thaliana transcriptional activator STYLISH1 regulates genes affecting stamen development, cell expansion and timing of flowering. Plant Mol Biol 78: 545-559. doi:10.1007/s11103-012-9888-Z

Su Y-H, Liu Y-B, Zhang X-S. 2011. Auxin-cytokinin interaction regulates meristem development. Mol Plant 4: 616-625. doi:10.1093/mp/ssr007

Su Z, Zhao L, Zhao Y, Li S, Won S, Cai H, Wang L, Li Z, Chen P, Qin Y, et al. 2017. The THO complex non-cell-autonomously represses female germline specification through the TAS3-ARF3 module. Curr Biol 27: 1597-1609.e2. doi:10.1016/j.cub.2017.05.021

Sun B, Xu Y, Ng KH, Ito T. 2009. A timing mechanism for stem cell maintenance and differentiation in the Arabidopsis floral meristem. Genes Dev 23: 1791-1804. doi:10 $.1101 /$ gad.1800409

Tabata R, Ikezaki M, Fujibe T, Aida M, Tian C, Ueno Y, Yamamoto KT, Machida Y, Nakamura K, Ishiguro S. 2010. Arabidopsis AUXIN RESPONSE FACTOR6 and 8 regulate jasmonic acid biosynthesis and floral organ development via repression of class $1 \mathrm{KNOX}$ genes. Plant Cell Physiol 51: 164-175. doi:10.1093/pcp/pcp176

Takada S, Hibara K, Ishida T, Tasaka M. 2001. The CUPSHAPED COTYLEDON1 gene of Arabidopsis regulates shoot apical meristem formation. Development 128: 1127-1135.

Takeda S, Matsumoto N, Okada K. 2004. RABBIT EARS, encoding a SUPERMAN-like zinc finger protein, regulates petal development in Arabidopsis thaliana. Development 131: 425-434. doi:10.1242/dev.00938
Tashiro S, Tian CE, Watahiki MK, Yamamoto KT. 2009. Changes in growth kinetics of stamen filaments cause inefficient pollination in massugu2, an auxin insensitive, dominant mutant of Arabidopsis thaliana. Physiol Plant 137: 175-187. doi:10.1111/j.1399-3054.2009.01271.x

Theißen G, Saedler H. 2001. Floral quartets. Nature 409: 469-471. doi:10.1038/35054172

Trigueros M, Navarrete-Gómez M, Sato S, Christensen SK, Pelaz S, Weigel D, Yanofsky MF, Ferrándiz C. 2009. The NGATHA genes direct style development in the Arabidopsis gynoecium. Plant Cell 21: 1394-1409. doi:10.1105/ tpc. 109.065508

Tucker SC. 2003. Floral development in legumes. Plant Physiol 131: 911-926. doi:10.1104/pp.102.017459

Van Mourik S, Kaufmann K, van Dijk ADJ, Angenent GC, Merks RMH, Molenaar J. 2012. Simulation of organ patterning on the floral meristem using a polar auxin transport model. PLoS ONE 7: e28762. doi:10.1371/journal .pone.0028762

Varaud E, Brioudes F, Szécsi J, Leroux J, Brown S, PerrotRechenmann C, Bendahmane M. 2011. AUXIN RESPONSE FACTOR8 regulates Arabidopsis petal growth by interacting with the bHLH transcription factor BIGPETALp. Plant Cell 23: 973-983. doi:10.1105/tpc.110 .081653

Vernoux T, Kronenberger J, Grandjean O, Laufs P, Traas J. 2000. PIN-FORMED 1 regulates cell fate at the periphery of the shoot apical meristem. 5165: 5157-5165.

Wang Q, Kohlen W, Rossmann S, Vernoux T, Theres K. 2014a. Auxin depletion from the leaf axil conditions competence for axillary meristem formation in Arabidopsis and tomato. Plant Cell 26: 2068-2079. doi:10.1105/tpc .114 .123059

Wang Y, Wang J, Shi B, Yu T, Qi J, Meyerowitz EM, Jiao Y. 2014b. The stem cell niche in leaf axils is established by auxin and cytokinin in Arabidopsis. Plant Cell 26: 20552067. doi:10.1105/tpc.114.123083

Wang Q, Hasson A, Rossmann S, Theres K. 2016. Divide et impera: boundaries shape the plant body and initiate new meristems. New Phytol 209: 485-498. doi:10.1111/nph .13641

Weigel D, Alvarez J, Smyth DR, Yanofsky MF, Meyerowitz EM. 1992. LEAFY controls floral meristem identity in Arabidopsis. Cell 69: 843-859. doi:10.1016/0092-8674 (92)90295-N

Wellmer F, Bowman JL, Davies B, Ferrándiz C, Fletcher JC, Franks RG, Graciet E, Gregis V, Ito T, Jack TP, et al. 2014. Flower development: open questions and future directions. Methods Mol Biol 1110: 103-124. doi:10.1007/ 978-1-4614-9408-9_5

Wu M-F, Tian Q, Reed JW. 2006. Arabidopsis microRNA167 controls patterns of ARF6 and ARF8 expression, and regulates both female and male reproduction. Development 133: 4211-4218. doi:10.1242/dev.02602

Wu M, Yamaguchi N, Xiao J, Bargmann B, Estelle M, Sang Y, Wagner D. 2015. Auxin-regulated chromatin switch directs acquisition of flower primordium founder fate. eLife 4: 1-19.

Xing S, Salinas M, Garcia-Molina A, Höhmann S, Berndtgen R, Huijser P. 2013. SPL8 and miR156-targeted SPL genes redundantly regulate Arabidopsis gynoecium differential patterning. Plant J 75: 566-577. doi:10.1111/tpj.12221 
Xu B, Li Z, Zhu Y, Wang H, Ma H, Dong A, Huang H. 2008 Arabidopsis genes $A S 1, A S 2$, and $J A G$ negatively regulate boundary-specifying genes to promote sepal and petal development. Plant Physiol 146: 566-575. doi:10.1104/ pp.107.113787

Xu Y, Prunet N, Gan E, Wang Y, Stewart D, Wellmer F, Huang J, Yamaguchi N, Tatsumi Y, Kojima M, et al. 2018. SUPERMAN regulates floral whorl boundaries through control of auxin biosynthesis. EMBO $J$ 37: e97499.

Xu XF, Wang B, Feng YF, Xue JS, Qian XX, Liu SQ, Zhou J, Yu YH, Yang NY, Xu P, et al. 2019. AUXIN RESPONSE FACTOR17 directly regulates MYB108 for anther dehiscence. Plant Physiol 181: 645-655. doi:10.1104/pp.19 .00576

Yadav S, Kumar H, Yadav RK. 2019. Local auxin biosynthesis promotes stem cell differentiation and organogenesis in Arabidopsis shoot apex. bioRxiv doi:10.1101/ 819342

Yamaguchi N, Wu MF, Winter CM, Berns MC, Nole-Wilson S, Yamaguchi A, Coupland G, Krizek B, Wagner D. 2013. A molecular framework for auxin-mediated initiation of flower primordia. Dev Cell 24: 271-282. doi:10.1016/j .devcel.2012.12.017

Yamaguchi N, Jeong CW, Nole-Wilson S, Krizek BA, Wagner D. 2016. AINTEGUMENTA and AINTEGU MENTA-LIKE6/PLETHORA3 induce LEAFY expression in response to auxin to promote the onset of flower formation in Arabidopsis. Plant Physiol 170: 283-293. doi:10 $.1104 /$ pp.15.00969

Yamaguchi N, Huang J, Xu Y, Tanoi K, Ito T. 2017. Finetuning of auxin homeostasis governs the transition from floral stem cell maintenance to gynoecium formation. Nat Commun 8: 1125. doi:10.1038/s41467-017-01252-6
Yamaguchi N, Huang J, Tatsumi Y, Abe M, Sugano SS, Kojima M, Takebayashi Y, Kiba T, Yokoyama R, Nishitani K, et al. 2018. Chromatin-mediated feed-forward auxin biosynthesis in floral meristem determinacy. Nat Commun 9: 5290. doi:10.1038/s41467-018-07763-0

Yang XY, Li JG, Pei M, Gu H, Chen ZL, Qu LJ. 2007. Overexpression of a flower-specific transcription factor gene AtMYB24 causes aberrant anther development. Plant Cell Rep 26: 219-228. doi:10.1007/s00299-006-0229-z

Yang C, Song J, Ferguson AC, Klisch D, Simpson K, Mo R, Taylor B, Mitsuda N, Wilson ZA. 2017. Transcription factor MYB26 is key to spatial specificity in anther secondary thickening formation. Plant Physiol 175: 333350. doi:10.1104/pp.17.00719

Yu H, Huang T. 2016. Molecular mechanisms of floral boundary formation in Arabidopsis. Int J Mol Sci 17: 317. doi:10.3390/ijms17030317

Žádníková P, Simon R. 2014. How boundaries control plant development. Curr Opin Plant Biol 17: 116-125. doi:10 .1016/j.pbi.2013.11.013

Zhang X, Zhou Y, Ding L, Wu Z, Liu R, Meyerowitz EM 2013. Transcription repressor HANABA TARANU controls flower development by integrating the actions of multiple hormones, floral organ specification genes, and GATA3 family genes in Arabidopsis. Plant Cell 25: 83101. doi:10.1105/tpc.112.107854

Zhao H, Liu L, Mo H, Qian L, Cao Y, Cui S, Li X, Ma L. 2013 The ATP-binding cassette transporter ABCB19 regulates postembryonic organ separation in Arabidopsis. PLoS ONE 8: e60809. doi:10.1371/journal.pone.0060809

Zhu M, Chen W, Mirabet V, Hong L, Bovio S, Strauss S, Schwarz EM, Tsugawa S, Wang Z, Smith RS, et al. 2020. Robust organ size requires robust timing of initiation orchestrated by focused auxin and cytokinin signalling. Nat Plants 6: 686-698. doi:10.1038/s41477-020-0666-7 


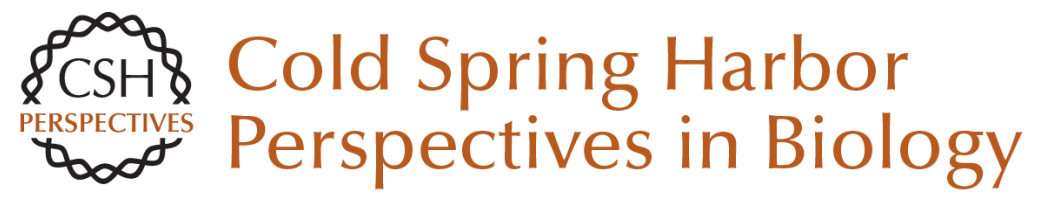

\section{Auxin and Flower Development: A Blossoming Field}

Mara Cucinotta, Alex Cavalleri, John William Chandler and Lucia Colombo

Cold Spring Harb Perspect Biol 2021; doi: 10.1101/cshperspect.a039974 originally published online December 22, 2020

\section{Subject Collection Auxin Signaling}

Fourteen Stations of Auxin Jirí Friml

Computational Models of Auxin-Driven Patterning in Shoots

Mikolaj Cieslak, Andrew Owens and Przemyslaw Prusinkiewicz

Auxin Transporters--A Biochemical View Ulrich Z. Hammes, Angus S. Murphy and Claus Schwechheimer

Structural Aspects of Auxin Signaling Nicholas Morffy and Lucia C. Strader

The Story of Auxin-Binding Protein 1 (ABP1) Richard Napier

Noncanonical Auxin Signaling Heather Marie McLaughlin, Aaron Chun Hou Ang and Lars Østergaard

Casting the Net--Connecting Auxin Signaling to the Plant Genome Yanfei Ma, Sebastian Wolf and Jan U. Lohmann

Auxin Plays Multiple Roles during Plant-Pathogen Interactions

Barbara N. Kunkel and Joshua M.B. Johnson
Auxin in Root Development

Suruchi Roychoudhry and Stefan Kepinski

Modeling Auxin Signaling in Roots: Auxin Computations

Jaap Rutten, Thea van den Berg and Kirsten ten Tusscher

The Systems and Synthetic Biology of Auxin $R$. Clay Wright, Britney L. Moss and Jennifer L. Nemhauser

Auxin Does the SAMba: Auxin Signaling in the

Shoot Apical Meristem Markéta Pernisová and Teva Vernoux

Chemical Biology in Auxin Research Ken-ichiro Hayashi

Uncovering How Auxin Optimizes Root Systems

Architecture in Response to Environmental

Stresses Nicola Leftley, Jason Banda, Bipin Pandey, et al.

Auxin Interactions with Other Hormones in Plant Development

Serina M. Mazzoni-Putman, Javier Brumos, Chengsong Zhao, et al.

No Time for Transcription--Rapid Auxin

Responses in Plants

Shiv Mani Dubey, Nelson B.C. Serre, Denisa Oulehlová, et al.

For additional articles in this collection, see http://cshperspectives.cshlp.org/cgi/collection/

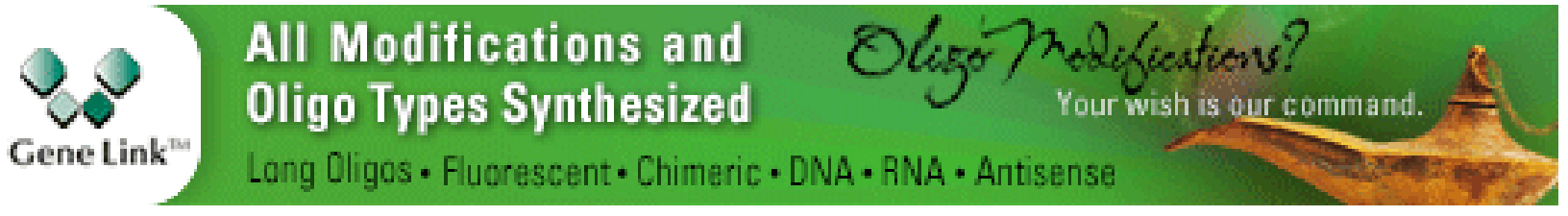

Copyright @ 2021 Cold Spring Harbor Laboratory Press; all rights reserved 
For additional articles in this collection, see http://cshperspectives.cshlp.org/cgi/collection/

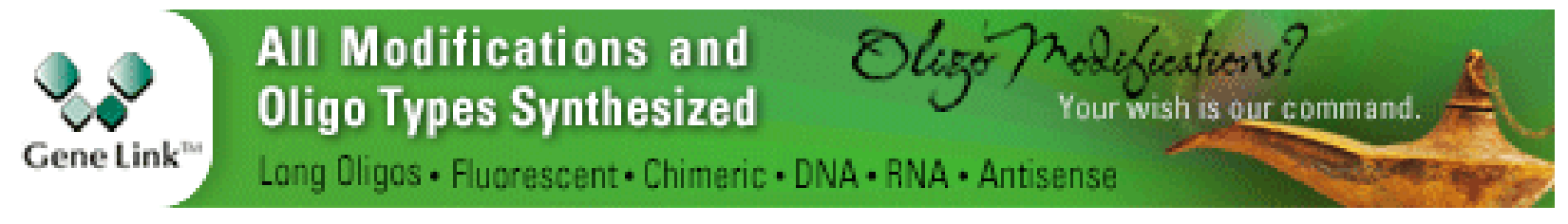

Copyright @ 2021 Cold Spring Harbor Laboratory Press; all rights reserved 